\title{
The Influence of Organizational Culture and Organizational Citizenship Behavior (OCB) on the Performance of Hotel Employees in Batam City with Organizational Commitment as Intervening Variables
}

\author{
Wasiman $^{1}$ \\ ${ }^{1}$ Putera Batam University Management, Indonesia, e-mail: wasiman903@gmail.com
}

\begin{abstract}
The purpose of this study was to determine the effect of organizational culture and organizational citizenship behavior (OCB) on the performance of hotel employees in Batam City with organizational commitment as an intervening variable. Respondents used in this study were employees of four-star hotels in Batam City with a total of 213 respondents. Data analysis method uses multiple linear data analysis and using SEM Amos program. The results of the study conclude that 1 . Organizational culture has a significant effect on the performance of four-star hotel employees in Batam City, the better the organizational culture can provide a greater impact on improving the performance of four-star hotel employees in Batam City. 2. Organizational culture has a significant effect on the organizational commitment of four-star hotels in Batam City, the better the organizational culture, the stronger the organizational commitment of employees. $3 \mathrm{OCB}$ affects the organizational commitment of four-star hotels in Batam City, the better the OCB behavior of employees, the stronger organizational commitment employee. 4 OCB affects the performance of employees of four-star hotels in Batam City, the better the behavior of OCB employees, the higher the performance. 5. Compelling organizational commitment to the performance of four-star hotel employees in Batam City, the better organizational commitment, the better the performance of four-star hotel employees in Batam City
\end{abstract}

Keywords: Organizational Culture, OCB, Organizational Commitment and Employee Performance

\section{Introduction}

Organizational culture is closely related to employee performance. Employee performance is the level of work achieved by employees with predetermined conditions (Simamora 2014: 314). According Simamora (2014: 314) also explains that there are three factors that affect performance, one of which is attitude. The good and bad attitude of an employee is influenced by the organizational culture because the values and norms contained therein can be used to direct employee attitudes / behavior. Organizational culture is also closely related to employee commitment. According to Robin and Judge (2013: 155) organizational commitment is a behavioral dimension that can be used to assess the tendency of employees to survive as members of an organization. A good organizational culture will increase the sense of belonging and commitment of organizational members to the organization and its working groups (Robbins and Judge, 2013: 36).

Formulation of the problem.

1. Does Organizational Culture have a significant effect on the performance of four-star hotel employees in Batam City?

2. Does Organizational Culture have a significant effect on the organizational commitment of fourstar hotels in Batam City?

3. Does Organizational Citizenship Behavior (OCB) significantly influence organizational commitment of four-star hotels in Batam City?

4. Does Organizational Citizenship Behavior (OCB) significantly influence the performance of four-star hotel employees in Batam City? 
5. Does organizational commitment have a significant effect on the performance of four-star hotel employees in Batam City?

Based on the above formula, the purpose of this study is to analyze and prove:

1. The influence of organizational culture on the performance of four-star hotel employees in Batam City?

2. The influence of organizational culture on the organizational commitment of four-star hotels in Batam City?

3. Effect of Organizational Citizenship Behavior (OCB) on organizational commitment of four-star hotels in Batam city?

4. Effect of Organizational Citizenship Behavior (OCB) on the performance of four-star hotel employees in Batam City?

5. Effect of organizational commitment on the performance of four-star hotel employees in Batam City

According to Schein (2008), organizational culture is a pattern of basic assumptions found or developed by a group of people when they learn to solve problems, adjust to the external environment, and integrate with the internal environment. These basic assumptions have been proven to be well implemented to solve the problems they face and are considered valid. Therefore, it is taught to new members as the right way to perceive, think and choose. According to Robbins (2012: 253) there are five functions of organizational culture, namely setting boundaries, bringing a sense of identity to members of the organization, facilitating commitment, increasing the stability of the social system and the mechanism of meaning and control that guides and shapes employee attitudes and behavior. Schein (2004: 25) divides the level of organizational culture into three parts, namely artifacts, basic values and assumptions. While the process of forming the organizational culture itself according to Robbins (2012: 261) states that the process of forming an organizational culture begins with the thought / philosophy of the founders of the organization, then determines the direction of selection of new organizational members by top management through socialization, then a culture is formed in an organization

Organizational Citizenship Behavior (OCB) can be created through organizational culture (Kusdi (2013: 111)). A good organizational culture will add a positive value to the smooth performance of the organization (Luthans in Riani, 2011: 8). The smooth performance of the organization must be linked to the effectiveness and efficiency of organizational actors in carrying out their tasks for the realization of organizational goals. A well-embedded organizational culture in an organization will provide a comfortable atmosphere for fellow employees. The awareness of the organization's tasks and vision that is supported by a strong organizational culture supports the development of Organizational Citizenship Behavior (OCB) (Kusdi, 2011: 110)

Organizational Citizenship Behavior (OCB) according to Robbins (2008: 31) is behavior conducted by an employee who exceeds formal work obligations but has a good impact because it supports organizational effectiveness. Aspects of OCB according to Organ et all (2010: 84) explain that:

1) Altruism. Behavior helps coworkers who have difficulties in situations that are being faced regarding the company's duties and personal problems. This aspect provides help that is not the responsibility of the main task.

2) Conscientiousness. Behavior that shows more effort by employees compared to company expectations. This behavior is voluntary without considering the rewards or awards that will be received. 3) Sportsmanship. Tolerance behavior shown by employees when the company is less than ideal without raising objections. This behavior supports the existence of a positive climate in work because of more polite behavior and working with others.

4) Courtesy. Maintain good relations with colleagues to avoid personal problems and tend to show other people's caring behavior. 
5) Civic Virtue. Behavior that dedicates itself to corporate responsibility such as following changes in the organization, taking the initiative to recommend a change for the efficiency and progress of the company. Some factors that are thought to influence OCB include: Organizational commitment (O'Reilly and Chatman, 1986; Eisenberger et al., 1990; Organ, 1990; Truckenbrodt, 2000), perceptions of leadership and organizational support, (Farh et al., 1990; Niehoff and Moorman, 1993; Smith et al., 1983; Van Dyne et al., 1994; Podsakoff et al., 2000), person organization fit (de Lara, 2008), Job satisfaction (Smith et al., 1983; Bateman and Organ, 1983; Moorman, 1993; Murphy et al., 2002), Psychological contract (Coyle-Shapiro, 2002; Turnley et al., 2003), perceptions of fairness Perception of fairness (Moorman et al., 1993; Tepper and Taylor , 2003) and justice and organizational justice (Moorman, 1991; Sheppard et al., 1992; Eskew, 1993; Tansky, 1993; Skarlicki and Latham, 1996).

An employee's commitment can be used to measure and evaluate the performance of these employees in the organization. According to knowing the commitment or not of the employees, the organization can determine the direction of policies that the company will set through strong and efficient human resources. Gibson (1996: 184) revealed that organizational commitment is the attachment of employees that is shown in identifying with organizational goals, feelings of involvement, and sense loyalty to the organization. There are three forms of organizational commitment according to Mayer and Allen in Luthans (2006: 249), namely:

1. Affective commitment, namely the emotional attachment of employees to the company.

2. Continuous commitment. That is a commitment based on losses if employees leave the company.

3. Normative commitment. That is a commitment caused by a feeling of having an obligation to keep on living in the company

Performance comes from understanding performance. There are also those who provide an understanding of performance as a result of work or work performance. But actually, performance has a broad meaning, not only the results of work, but includes how the work process takes place (Wibowo, 2012: 7).

Simamora (2010: 48) further stated that performance refers to the level of achievement of tasks that shape an employee's work and reflects how well the employee meets the requirements of a job but is often misinterpreted as an effort that reflects the energy released, performance is measured in terms of results. Armstrong and Baron (Wibowo, 2007: 7) explain that performance is a work that has a strong relationship with the organization's strategic goals, customer satisfaction, and economic contribution. Hypothesis.

H1. Organizational Culture has a significant effect on the performance of four-star hotel employees in the city of Batam

H2. Organizational Culture has a significant effect on the organizational commitment of four-star hotels in Batam City

H3. Organizational citizenship behavior (OCB) has a significant influence on the organizational commitment of four-star hotels in Batam city

H4. Organizational citizenship behavior (OCB) has a significant effect on the performance of fourstar hotel employees in the city of Batam

H5. Organizational commitment has a significant effect on the performance of four-star hotel employees in the city of Batam 


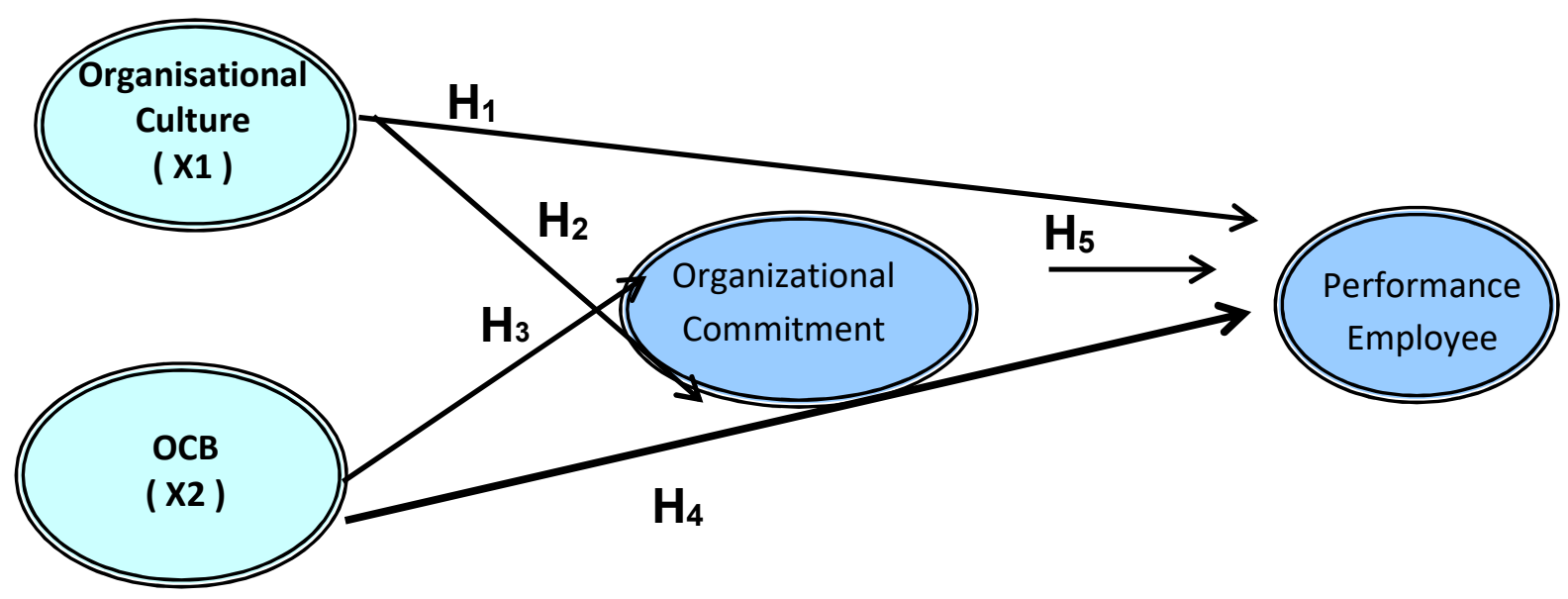

Figure 1. Structural Model

\section{Research Methodology}

The design of this study originated from a quantitative problem and limited the problems that exist in the formulation of the problem. The formulation of the problem is established in the sentence of the question, then the researcher uses the theory to answer it. Sugiyono (2014:23) states that "the design of the research must be specific, clear and detailed, determined constantly from the beginning, so that it is a step-by-step grasp". The research design is related between the variables $\mathrm{X}$ and the $\mathrm{Y}$ variables, namely the organizational culture (X1), the behavior of the organizational citizenship (OCB) (X2) on the organizational commitment with the intervening variables $(Z)$ and its impact on the performance of employees (Y) four-star hotels in Batam City

The variables used in this study are exogenous variables that consist of the organizational culture (X1) and the OCB (X2) indigenous variables, that is, the employee's performance (Y) and the organizational commitment as intermediate variables.

According to Sugiono (2012: 80), he suggests that: Population is an area of generalization that consists of objects / subjects that have certain qualities and characteristics defined by the researcher to be studied and then conclusions are drawn. So, the population is not just people, but also objects and other natural objects. The population is not only the quantity that exists in the object / subject studied, but it also includes all the properties / characteristic that the subject / object possesses. The population in this study is 550 inhabitants who are employees of four-star hotels in Batam City

According to Sugiyono (2011: 118) the sample is part of the number and characteristics possessed by the population. What is learned from the sample conclusions will be applicable to the population. "For that sample taken from the population must be truly representative. By using the Slovin formula with an error rate of 5\%, the sample used in this study was 213 samples.

In this study data collection techniques were carried out by interview (interview), questionnaire (questionnaire), observation (observation), and a combination of the three.

The location of the research location in this study was a four-star hotel in Batam City

\section{Result and Discussion}

The discussion of each variable's influence can be explained as follows: H1. The Influence of Organizational Culture on Employee Performance

The results of research and testing using SEM with AMOS v.20 Software indicate that organizational culture has a significant effect on employee performance at Four Star Hotels in Batam City. The 
estimation results of the parameters of organizational culture influence on employee performance shows significant results with the CR value greater than 1.94, and the significance value (p-value) is smaller than $5 \%$, meaning that organizational culture is able to have a large impact on employee performance. Thus, the first hypothesis which states that organizational culture has a significant effect on employee performance at Four Star Hotels in Batam City, is acceptable.

The results of this study are consistent with the results of Koesmono's (2005) study which concluded that organizational culture influences employee performance. Taurisa and Ratnawati (2012) in their research also concluded that organizational culture had a positive and significant effect on employee performance. Research by Arius Kambu, Eka Afnan Troena, Surachman, and Margono Setiawan in 2011 entitled "The Influence of Exchange Leaders, Perceptions of Organizational Support, Ethnic Culture of Papua and Organizational Citizenship Behavior on Employee Performance in the Secretary of the Papua Province". The results of this study prove that good Exchange Leaders have not been able to form OCB and improve employee performance

H2. The Influence of Organizational Culture on Organizational Commitments

The results of research and testing using SEM with AMOS v.20 Software indicate the influence of organizational culture on employee organizational commitment at Four Star Hotels in Batam City. The estimation results of the parameters of the influence of organizational culture on organizational commitment show significant results with the CR value greater than 1.94 , and the significance value ( $p$ value) is smaller than $5 \%$, so the second hypothesis stating that organizational culture has a significant effect on organizational commitment employees at Four Star Hotels in Batam City, can be accepted.

The results of this study are consistent with Robbins (2005: 110) statement that the culture of employee spirituality in organizations is positively related to employee satisfaction creativity, team performance and organizational commitment. This is supported by research conducted by Imaniyati (2007) that organizational culture has a very large and most significant influence on organizational commitment. Primanda (2008) and Fajrina (2009) also concluded that organizational culture has a positive effect on employee commitment.

H3. Effect of OCB on organizational commitment

The results of research and testing using SEM with AMOS v.20 Software also showed the influence of OCB on employee organizational commitment at Four Star Hotels in Batam City. The parameter estimation results of the influence of OCB on organizational commitment show significant results with CR value greater than 1.96, and the significance value (p-value) is smaller than $5 \%$, so the fifth hypothesis states that OCB has a significant effect on employee organizational commitment at Four Star Hotels in Batam City, can also be accepted.

The results of this study are consistent with the statements of Robbin and Judge (2008) that organizational citizenship behavior can arise from various factors in the organization, including because of job satisfaction and employee commitment. When employees are satisfied with what is in the organization, the employee will provide maximum and best performance results. Likewise, with employees who have a high commitment to the organization, will do anything to advance the company because they believe and believe in the organization where the employee works (Luthans, 2005). employees who have a high commitment to the company, the employee wholeheartedly has satisfaction in working, and is willing to take actions aimed at advancing the company.

H4 Effect of OCB on Employee Performance

The results of research and testing using SEM with AMOS v.20 Software also showed the influence of OCB on employee performance at Four Star Hotels in Batam City. Parameter estimation results of OCB influence on employee performance showed significant results with CR value greater than 1.93, and significance value (p-value) smaller than $5 \%$, so the twelfth hypothesis which states that OCB has a significant effect on employee performance on Four Star Hotels in Batam City, can also be accepted. 
The results of this study are consistent with the research conducted by Deovani Yanuardana(2014), "The Influence of Organizational Citizenship Behavior (OCB) on Employee Performance in IN Maulana Malik Ibrahim Malang" The results of the study indicate that OCB (altruism, sportsmanship, courtesy, civic virtue, conscientiousness) variables partially or manually have a significant effect on performance. While the variables that have a dominant influence on performance are the variables of conscientiousness. Another study related to OCB was a study conducted by Yumna Dalian Putri and Hamidah Nayati Utami with the title Influence of Organizational Citizenship Behavior (OCB) on Employee Performance (Study on Nursing Staff at Batu Baptist Hospital in Malang). The results of the study concluded that simultaneous hypothesis testing (Test F). The results of the research and the results of hypothesis testing that have been conducted indicate that there is a significant influence on Test F, namely between the OCB variables namely Altruism (X1), Conscientiousness (X2), sportsmanship (X3), Courtesy (X4), Civic Virtue (X5 ) as an independent variable simultaneously on employee performance. H5 Effect of Organizational Commitment to Employee Performance

The results of research and testing using SEM with AMOS v.20 Software also showed the influence of organizational commitment on employee performance at Four Star Hotels in Batam City. Parameter estimation results of the influence of organizational commitment on employee performance shows significant results with $\mathrm{CR}$ value greater than 1.92, and significance value (p-value) smaller than $5 \%$, so the thirteenth hypothesis which states that organizational commitment has a significant effect on performance employees at Four Star Hotels in Batam City, can also be accepted.

The results of this study are consistent with the research conducted by Diana Sulianti K.L. Tobing (2009) entitled "The Effect of Organizational Commitment and Job Satisfaction on the Performance of Employees of PT. Nusantara Plantation III in North Sumatra". The variables studied were affective commitment, continuance commitment, normative commitment, job satisfaction and employee performance. With the aim of the study to examine the relationship between organizational commitment, job satisfaction, and job performance. Obtaining results using Structural Equation Modeling (SEM) analysis tools that show affective, continuance and normative commitment positively influence job satisfaction, job satisfaction has a positive effect on the performance of employees of PT.Perkebunan Nusantara III in North Sumatra. Other research Dian Kristanto, et al (2012) entitled "The Effect of Job Satisfaction on Employee Performance with Organizational Commitment as Intervening Variables (Study in Tugurejo Hospital Semarang)". Has the aim to analyze the effect of job satisfaction on organizational commitment, the influence of organizational commitment on employee performance, and the influence of job satisfaction on employee performance. The variables studied are job satisfaction, organizational commitment and employee performance. Dian Kristanto's research, et al (2012) used Path analysis tools to analyze or analyze paths and the results of these studies showed the influence of job satisfaction on employee performance through organizational commitment as an intervening variable

\section{Conclusion}

The research variable consists of organizational culture, and OCB, organizational commitment, and employee performance, it can be concluded as follows:

1. Organizational culture has a significant effect on employee performance, the better the organizational culture is capable of having a large impact on improving employee performance.

2. Organizational culture has a significant effect on organizational commitment, the better the organizational culture, the stronger the organizational commitment of employees.

3. OCB has a significant effect on organizational commitment, the better the OCB behavior of employees, the stronger the organizational commitment of employees.

4. OCB has a significant effect on employee performance, the better the OCB behavior of employees, the higher the performance. 
5. Organizational commitment has a significant effect on employee performance, the better the organizational commitment, the higher the employee's performance

\section{References}

Brahmasari, Ida Ayu and Agus Suprayetno, (2008), The Effect of Work Motivation, Leadership, and Organizational Culture on Employee Job Satisfaction and Its Impact on Company Performance (Case study at PT. Pei Hei International Wiratama Indonesia). Jurna Management and Entrepreneurship. Vol. 10, September: 124-135

Fred Luthans, (2006), Organizational Behavior. Ten Edition, PT. Andi: Yogyakarta

Herskowitz, Melville in Kusdi (2012: 97) Organizational Culture. The fifth print. Jakarta: Ghalia Indonesia

Organ, D.W. and Lingle, A. 2010. Personality, satisfaction and Organizational Commitment. Journal of Social Psychology, Vol135, p 339-350.

Riani. Asri Laksmi, (2013) Current Human Resource Management, Graha Ilmu, Yogyakarta.

Robbins. Stephen P, (2008), Complete Tenth Edition Organizational Behavior, Interpreting. Benjamin Molan, Gramedia Group Index, Jakarta.

Robbins, S. (2012). Organizational behavior. Jakarta: PT. Gramedia Group Index

Robbins, P.Stephen and Timothy A. Judge. (2013). Organizational behavior. Salemba Four. Jakarta

Simamora, (2010). Human Resource Management, Edition 4. Yogyakarta: STIE YKPN

Simamora (2014), Making Employees More Productive in the Long Term (Management HR). STIE YKPN, Yogakarta

Sugiyono (2011). Qualitative quantitative research methods and R \& D. Alfabeta

Sugiyono, 2012. Understanding Qualitative and Quantitative Research on R \& D.Material: Alfabeta

Sugiyono. 2014. Statistics for Research. Bandung: Alfabeta

Schein, E. H. (2008). Organizational Culture and Leadership. San Francisco: Jossey-Bass

Wibowo. (2007). Performance Management. Jakarta: PT. Raja GrafindoParsada.

Wibowo. 2012. Performance Management (3rd Edition). Jakarta: Rajawali Press. 